\title{
BIBECHANA
}

A Multidisciplinary Journal of Science, Technology and Mathematics ISSN 2091-0762 (Print), 2382-5340 (Online)

Journal homepage: http://nepjol.info/index.php/BIBECHANA

Publisher: Research Council of Science and Technology, Biratnagar, Nepal

\section{Effect of additional side groups on the vibrational frequencies of benzoquinone molecules}

\author{
Nabin Kumar Raut, Hari Prasad Lamichhane* \\ Central Department of Physics Tribhuvan University, Kirtipur, Kathmandu, Nepal \\ *E-mail:- hlamichhane1@ gmail.com
}

Article history: Received 30 May, 2016; Accepted 29 September, 2016

DOI: http://dx.doi.org/10.3126/bibechana.v14i0.15860

This work is licensed under the Creative Commons CC BY-NC License.

https://creativecommons.org/licenses/by-nc/4.0/

(c) (i) (8)

\begin{abstract}
The present work enumerates detailed computational investigation into the IR spectra in gas phase and in solvent of 1, 4- Benzoquinone family (benzoquinone (BQ), duroquinone (DQ), plastoquinone (PQ), ubiquinone (UQ), and dimethoxy dimethyl benzoquinone (MQo)). In the spectra of BQ, PQ, and DQ, we observed separate intense carbonyl $(\mathrm{C}=\mathrm{O})$ and $\mathrm{C}=\mathrm{C}$ bands respectively around $1730 \mathrm{~cm}^{-1}$ (intense), 1645 $\mathrm{cm}^{-1}$ (weak). On the other hand, for UQ and MQo, three prominent bands around 1652, 1703, and 1733 $\mathrm{cm}^{-1}$ were observed, where two $\mathrm{C}=\mathrm{O}$ modes were uncoupled but one of the carbonyl is strongly coupled with $\mathrm{C}=\mathrm{C}$ vibrations. The additional methyl groups downshift the intense carbonyl bands and upshift $\mathrm{C}=\mathrm{C}$ mode frequencies. The carbonyl modes further downshifted in the solvent phase calculation.
\end{abstract}

Keywords: Photosynthesis; Reaction center; Benzoquinone; IR spectra; $\mathrm{Q}_{\mathrm{A}}, \mathrm{Q}_{\mathrm{B}}$

\section{Introduction}

Quinone serves as a coupler of electron and proton transfers in vivo in energy-transducing membrane for respiration and photosynthesis [1-4]. Based on nature of work, not on types, quinones in the reaction center $(\mathrm{RC})$ are classified as $\mathrm{Q}_{\mathrm{A}}$ (primary quinone) and $\mathrm{Q}_{\mathrm{B}}$ (secondary quinone). They can be chemically identical or different depending upon RC. For example, ubiquinone in Rb. sphaeroids and menaquinone in $C f$. aurantiacus $\mathrm{RC}$ works as both $\mathrm{Q}_{\mathrm{A}}$ and $\mathrm{Q}_{\mathrm{B}}$, in contrast in Chromatium or $R p$. viridis $\mathrm{RC}$ menaquinone is $\mathrm{Q}_{\mathrm{A}}$ and ubiquinone is $\mathrm{Q}_{\mathrm{B}}$. However, each of them has to complete significantly different task. Here, $\mathrm{Q}_{\mathrm{A}}$ works as transporter of electron and undergoes only single redox steps, while $\mathrm{Q}_{\mathrm{B}}$ works like recipient and has to go through two redox steps. Indeed, their mutual working leads to the proton-coupled electron transport reaction. The former can transport an electron to latter at a time until it gets two 
electrons. Eventually after receiving two electrons, $\mathrm{Q}_{\mathrm{B}}$ gets two protons from protein membrane forming $\mathrm{Q}_{\mathrm{B}} \mathrm{H}_{2}$ i.e. quinol which then leaves the reaction center.

$$
\mathrm{Q}_{\mathrm{B}}+2 \mathrm{e}^{-}+2 \mathrm{H}^{+} \Rightarrow \mathrm{Q}_{\mathrm{B}} \mathrm{H}_{2}
$$

$\mathrm{Q}_{B} \mathrm{H}_{2}$ leaves the binding site and a new $\mathrm{Q}_{B}$ occupies the vacant space. The quinol $\left(\mathrm{Q}_{B} \mathrm{H}_{2}\right)$ releases two hydrogen atoms whenever it reaches the place of higher redox potential [3]. Thus, this process creates a potential gradient across the photosynthetic membrane which drives ATP synthesis reaction [3]. Moreover, in purple bacteria $\mathrm{RC}$, the electron transfer from $\mathrm{Q}_{\mathrm{A}}$ to $\mathrm{Q}_{\mathrm{B}}$ spans a distance of $15 \AA$ (edge to edge) and are linked by H-bonds through a His- $\mathrm{Fe}^{2+}$-His complex [4]. On the other hand, the process of proton and electron transfer by a quinone is in reverse direction in respiration to that of photosynthesis [3]. Hence, study of quinones is so important for the understanding of reaction center and eventually about photosynthesis and respiration, which is essential for the survival of living things.

\section{Materials and Methods}

By using hybrid density functional theory (DFT) method we have done geometrical optimization and vibrational frequency calculations, employing B3LYP functional and the 6-31G+(d) basis within Gaussian 03 [5]. The solvent phase calculation employs IEFPCM method in carbon tetrachloride $\left(\mathrm{CCl}_{4}\right)$ solvent.

\section{Results and Discussions}

\section{1, 4-Benzoquinone Family}

Here, we have studied IR spectra and solvent effect of 1, 4-Benzoquinone family by dividing it into the two classes, which are Benzoquinone with and without methoxy side group.

\section{a. Benzoquinone without Methoxy Side Group \\ i. Structure and Numbering of $\mathrm{BQ}, \mathrm{PQ}$, and DQ}
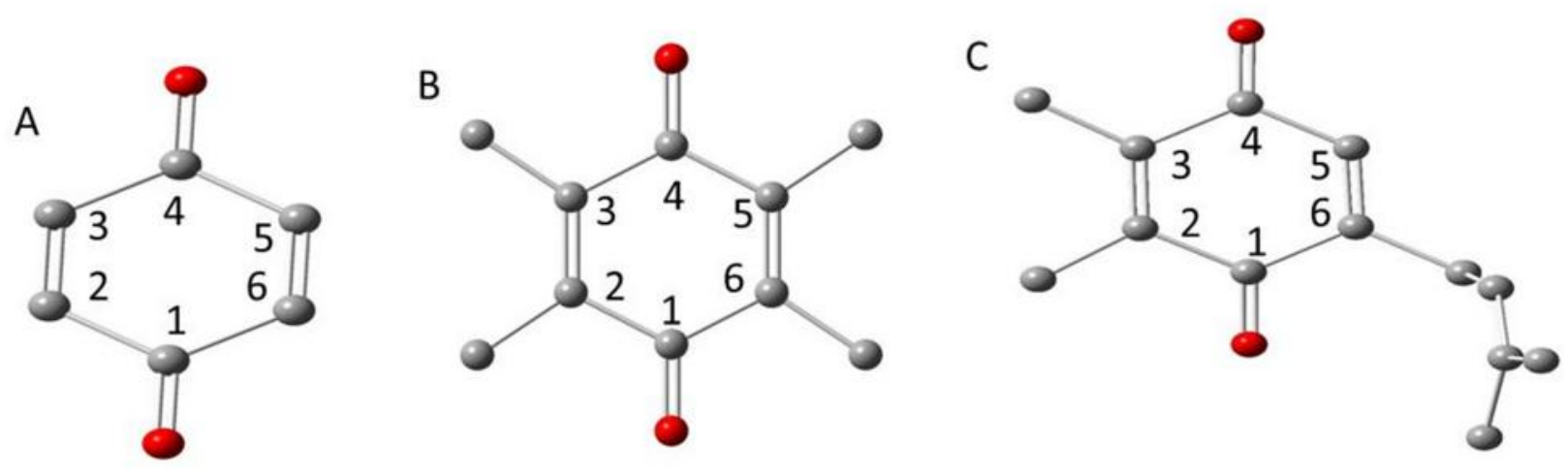

Fig. 1: Structure and numbering for (A) Benzoquinone (BQ), (B) Duroquinone (DQ), (C) plastoquinone (PQ). For the sake of simplicity the hydrogen atoms have been removed. 
Figure (1) shows structure and numbering scheme for benzoquinone without methoxy side groups (BQ, $\mathrm{PQ}$, and DQ). They have a quinone ring and differ from one another by particular functional group. Out of three, benzoquinone (BQ) has simplest structure and by replacing all of its hydrogen atom by methyl side group we can get duroquinone (DQ). Similarly, by replacing hydrogen atoms at the positions $\mathrm{C}_{2}$ and $\mathrm{C}_{3}$ by methyl groups and at $\mathrm{C}_{6}$ by isoprene unit we can get plastoquinone (PQ). The information of fuctional groups is summarized in table (1).

Table 1: Summary side groups in BQ, PQ, and DQ.

\begin{tabular}{|c|c|c|c|c|}
\hline \multirow{2}{*}{$1,4-\mathrm{BQ}$} & \multicolumn{4}{|c|}{ Side Groups } \\
\cline { 2 - 5 } & $\mathrm{C}_{2}$ & $\mathrm{C}_{3}$ & $\mathrm{C}_{5}$ & $\mathrm{C}_{6}$ \\
\hline $\mathrm{BQ}$ & $\mathrm{H}$ & $\mathrm{H}$ & $\mathrm{H}$ & $\mathrm{H}$ \\
\hline $\mathrm{DQ}$ & $\mathrm{CH}_{3}$ & $\mathrm{CH}_{3}$ & $\mathrm{CH}_{3}$ & $\mathrm{CH}_{3}$ \\
\hline PQ & $\mathrm{CH}_{3}$ & $\mathrm{CH}_{3}$ & $\mathrm{H}$ & Isoprene Unit \\
\hline
\end{tabular}

\section{ii. The IR Spectra of $B Q, P Q$, and DQ}

Calculated IR spectra of BQ, DQ, and PQ are shown in the figure (2) and (3). Figure (2) shows these three quinones and their corresponding spectra. On the other hand, figure (3) shows comparative spectra of all three of them. We have chosen spectra in the region $1800-1600 \mathrm{~cm}^{-1}$ because experimentally detectable carbonyl $(\mathrm{C}=\mathrm{O})$ and $\mathrm{C}=\mathrm{C}$ vibrations lie in this region. From figure (2) we observed that, in the IR spectra respectively of $\mathrm{BQ} / \mathrm{DQ} / \mathrm{PQ}$, the weak band is at 1651/1675/1663 $\mathrm{cm}^{-1}$ and are due to an out-ofphase vibration of the $\mathrm{C}=\mathrm{C}_{\mathrm{r}}$ groups $\left(\mathrm{C}_{2}=\mathrm{C}_{3}\right.$ and $\left.\mathrm{C}_{5}=\mathrm{C}_{6}\right)$ of the quinone ring. Given the antisymmetric nature of vibration it is very weakly Raman Active (data not included). In addition to that, a highly intense IR band respectively of them is found at $1735 / 1707 / 1714 \mathrm{~cm}^{-1}$ and are due to out-of-phase $\mathrm{C}=\mathrm{O}$ vibration. These modes also have asymmetric nature of vibration again they have weak Raman activities. Although not always true, as a general rule, band that are weak in Raman spectra are often strong in IR spectra [6].

By analyzing figure (3), we can conclude that BQ, DQ, and PQ have similar nature of spectra. Indeed, all of them have one intense and one weak band. Which means, addition of methyl and isoprene side group, respectively, in BQ to get DQ and PQ does not really change the nature of the spectra. However, addition of methyl side groups lowered the band positions carbonyl vibrations in proportion to the number of methyl groups.

\section{iii. The Solvent Effect}

Table (2) shows bond length of carbonyl group and $\mathrm{C}=\mathrm{C}_{\mathrm{r}}\left(\mathrm{C}_{2}=\mathrm{C}_{3}\right.$ and $\left.\mathrm{C}_{5}=\mathrm{C}_{6}\right)$ of optimized quinone structure in gas phase and $\mathrm{CCl}_{4}$. The $1 \mathrm{AIJ}$ crystal structure [7] indicates that the $\mathrm{C}_{1}=\mathrm{O}$ bond is marginally longer than the $\mathrm{C}_{4}=\mathrm{O}$ bond (1.234 versus $1.232 \AA$ ). The $\mathrm{C}_{1}=\mathrm{O}$ and $\mathrm{C}_{4}=\mathrm{O}$ bond length of $\mathrm{BQ}, \mathrm{DQ}$, and PQ were found shorter in the gas phase than that of the corresponding length in the $\mathrm{CCl}_{4}$. Among all three, BQ got maximum elongation $(0.003 \AA)$ in both $\mathrm{C}_{1}=\mathrm{O}$ and $\mathrm{C}_{4}=\mathrm{O}$ bond in solvent phase calculation. In 
opposite, they got minimum elongation $(0.001 \AA)$ in case of PQ. This change in length is due to increase in value of dielectric constant.
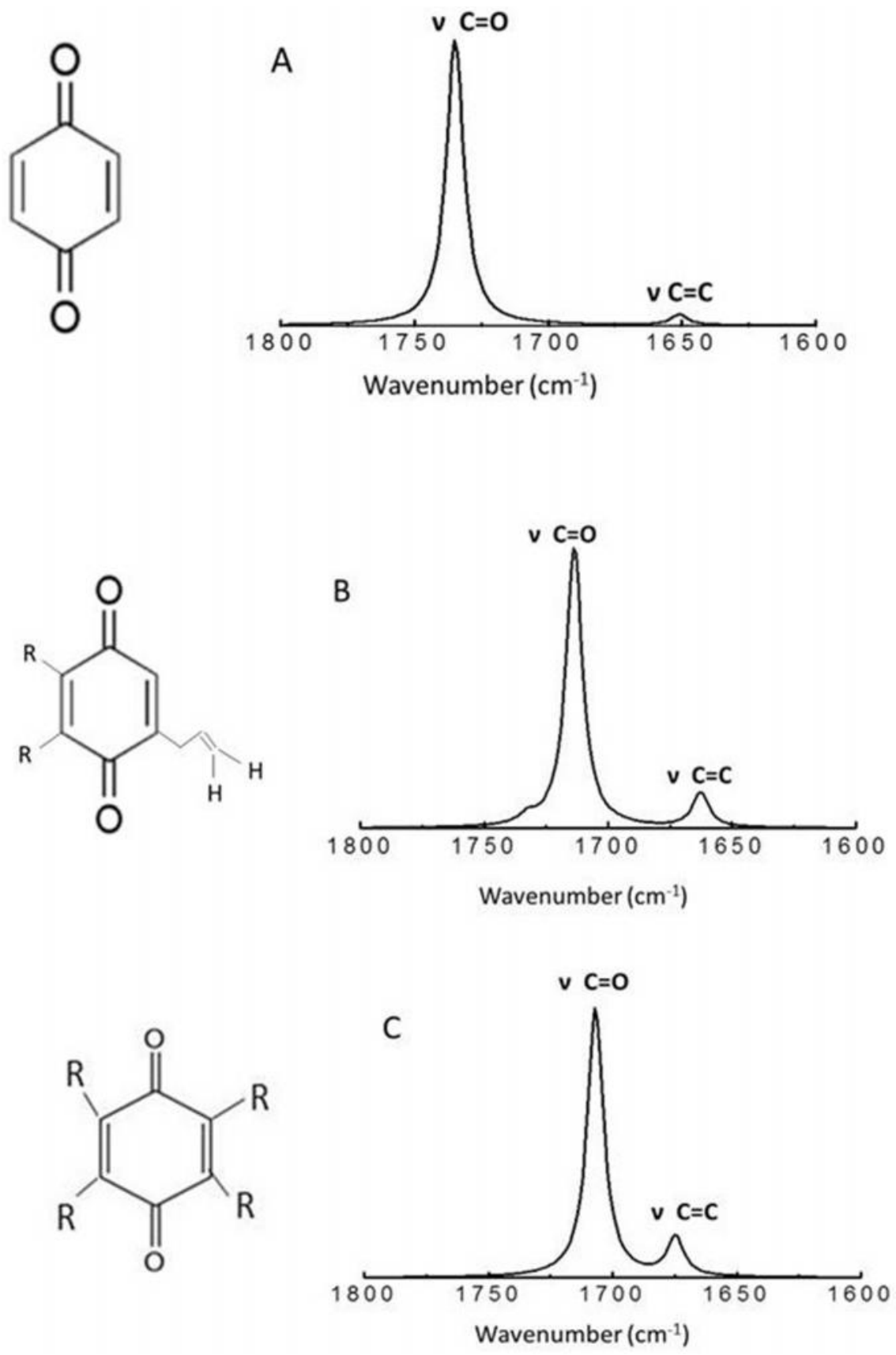

Fig. 2: Structure and gas phase calculated IR spectra in the $\mathrm{C}=\mathrm{O}$ and $\mathrm{C}=\mathrm{C}$ vibrating region for the (A) Benzoquinone, (B) Plastoquinone, and (C) Duroquinone. For the sake of simplicity $\mathrm{R}$ is written instead of $\mathrm{CH}_{3}$. 


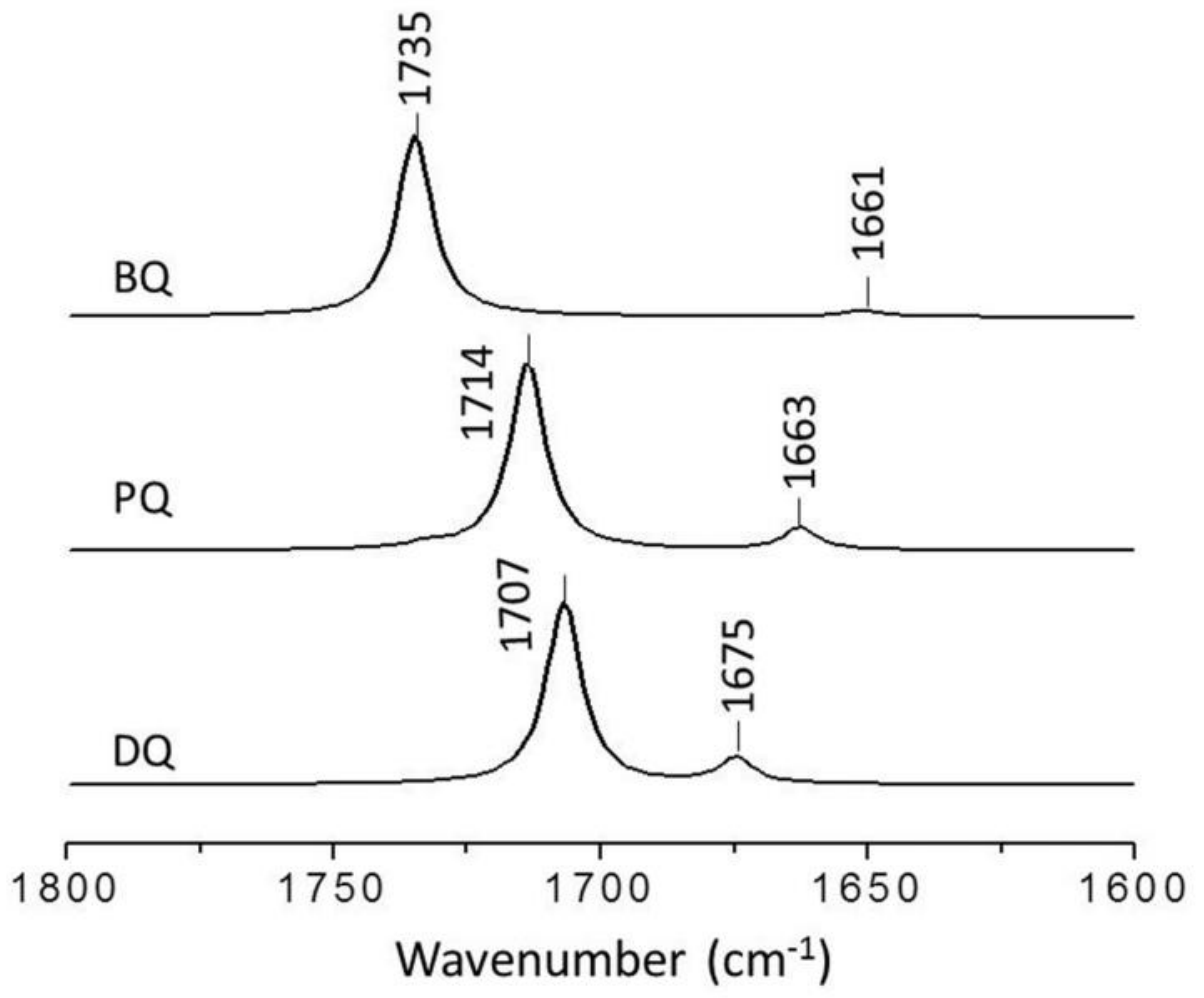

Fig. 3: Calculated IR absorption spectra of $B Q, D Q$, and $P Q$ in gas phase. The spectra are generated from the calculated stick spectra by convolving with Gaussian function of wavenumber $4 \mathrm{~cm}^{-1}$.

Furthermore, 1AIJ crystal structure [7] indicates that the $\mathrm{C}_{2}=\mathrm{C}_{3}$ bond is shorter than the $\mathrm{C}_{5}=\mathrm{C}_{6}$ Bond (1.404 versus $1.419 \AA$ ). In contrast, for the case of $\mathrm{BQ}, \mathrm{DQ}$, and $\mathrm{PQ}$, in both $\mathrm{CCl}_{4}$ and gas phase calculation $\mathrm{C}_{2}=\mathrm{C}_{3}$ and $\mathrm{C}_{5}=\mathrm{C}_{6}$ are equal. Since, in the gas phase or in $\mathrm{CCl}_{4}$ there is no effect of hydrogen bonding but in the protein environment i.e. in the crystal structure there is effect of hydrogen atom neighbor molecules which is difference of the bond length observed here with the bond length $\mathrm{C}=\mathrm{C}$ and $\mathrm{C}=\mathrm{O}$ group in crystal structure.

So, it can be concluded that calculation of quinone in solvent does effect in carbonyl group but effect is almost negligible for $\mathrm{C}=\mathrm{C}$ bond of quinone ring. Which suggested that the solvent not much constrain the quinone ring.

Table 2: Bond length of carbonyl group and $\mathrm{C}=\mathrm{C}_{\mathrm{r}}$ in $(\AA)$ unit of optimized structure of BQ, DQ, and PQ in Gas Phase (GP), $\mathrm{CCl}_{4}$, and Crystal Structure (CS).

\begin{tabular}{|c|c|c|c|c|c|c|c|c|c|c|c|c|}
\hline Types & \multicolumn{3}{|c|}{$\mathrm{C}_{1}=\mathrm{O}$} & \multicolumn{3}{c|}{$\mathrm{C}_{4}=\mathrm{O}$} & \multicolumn{3}{c|}{$\mathrm{C}_{2}=\mathrm{C}_{3}$} & \multicolumn{3}{c|}{$\mathrm{C}_{5}=\mathrm{C}_{6}$} \\
& \multicolumn{1}{|c|}{$\mathrm{GP}$} & $\mathrm{CCl}_{4}$ & $\mathrm{CS}$ & $\mathrm{GP}$ & $\mathrm{CCl}_{4}$ & $\mathrm{CS}$ & $\mathrm{GP}$ & $\mathrm{CCl}_{4}$ & $\mathrm{CS}$ & $\mathrm{GP}$ & $\mathrm{CCl}_{4}$ & $\mathrm{CS}$ \\
\hline $\mathrm{BQ}$ & 1.227 & 1.230 & 1.234 & 1.227 & 1.230 & 1.232 & 1.345 & 1.345 & 1.404 & 1.345 & 1.345 & 1.419 \\
\hline $\mathrm{DQ}$ & 1.230 & 1.232 & 1.234 & 1.230 & 1.232 & 1.232 & 1.356 & 1.356 & 1.404 & 1.356 & 1.356 & 1.419 \\
\hline $\mathrm{PQ}$ & 1.229 & 1.230 & 1.234 & 1.230 & 1.233 & 1.232 & 1.358 & 1.358 & 1.404 & 1.347 & 1.347 & 1.419 \\
\hline
\end{tabular}


Figure (4) shows comparative IR spectra of $\mathrm{BQ}, \mathrm{DQ}$, and PQ in gas phase and $\mathrm{CCl}_{4}$. From the figure it is obvious that frequency decreases in solvent $\left(\mathrm{CCl}_{4}\right)$ than that of in the gas phase calculation. In fact, there is general trend of lowering of frequency in intense band but case is not true for weak band. The cause of the intense band is due to asymmetric $\mathrm{C}=\mathrm{O}$ vibration, while that of weak band is due to asymmetric $\mathrm{C}=\mathrm{C}_{\mathrm{r}}$, $\mathrm{C}_{2}=\mathrm{C}_{3}$ and $\mathrm{C}_{5}=\mathrm{C}_{6}$, vibration. The force constant is inversely proportional to the bond length and directly proportional to the frequency i.e. frequency (f) $\alpha$ force constant (k) $\alpha\{1 /$ bond length (l) $\}$ [8]. Thus, increase in bond length in $\mathrm{C}_{1}=\mathrm{O}$ and $\mathrm{C}_{4}=\mathrm{O}$ that calculated in solvent than in gas phase results decrease in frequency for intense band \{figure (4) and table (2)\}. Our results also indicate frequencies shift and bond lengths shift are inversely proportional under calculation in solvent than in gas phase.

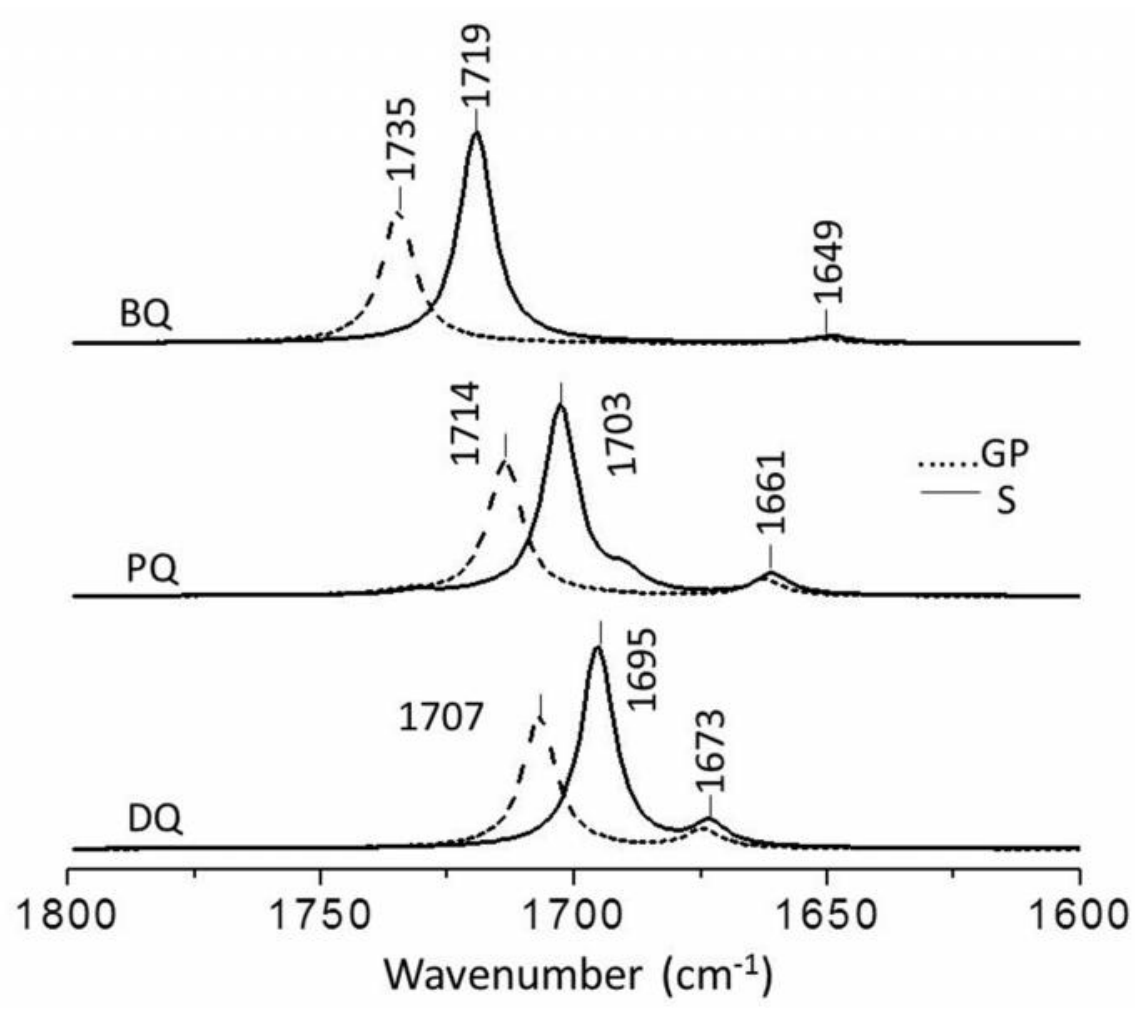

Fig. 4: Comparative spectra of $\mathrm{BQ}, \mathrm{DQ}$, and $\mathrm{PQ}$ in gas phase and $\mathrm{CCl}_{4}$. The Spectra are generated from the calculated stick spectra by convolving with Gaussian function of wavenumber $4 \mathrm{~cm}^{-1}$.

\section{b. Benzoquinone with Methoxy Side Group}

\section{i. Structure and Numbering of UQ and MQo}

The structure and numbering scheme for benzoquinone with methoxy side group (MQo and UQ) is shown in figure (5). Both of them have methoxy group at $\mathrm{C}_{2}$ and $\mathrm{C}_{3}$ and methyl at $\mathrm{C}_{5}$. The key component that distinguishes both of them is the functional group at $\mathrm{C}_{5}$. UQ has isoprene unit at that position, while $\mathrm{MQ}_{\mathrm{O}}$ has methyl side group. 

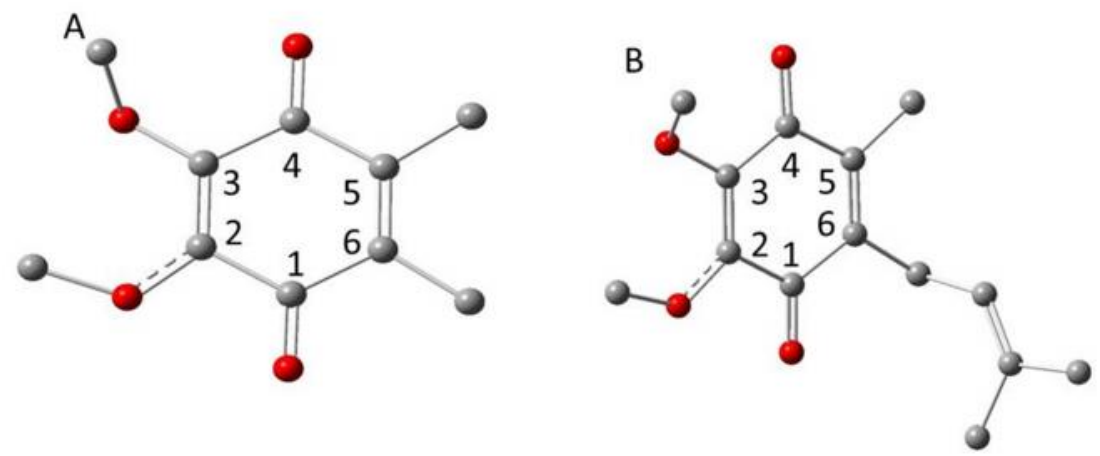

Fig. 5: Structure and numbering for (A) 2, 3-dimethoxy-5, 6-dimethyl benzoquinone (MQo) and (B) Ubiquinone (UQ). For the sake of simplicity the hydrogen atoms have been removed.

\section{ii. The IR Spectra of UQ and MQo}

Here, IR spectra of two methoxy containing benzoquinones (MQo and UQ) are shown in figure (6) and (7) in the region of 1800-1600 $\mathrm{cm}^{-1}$. Actually, figure (6) shows structure of MQo and UQ and their corresponding IR spectra with different modes of vibration. On the other hand, figure (7) shows the comparative spectra between them.<smiles>[R]C1=C([R])C(=O)C([2H])=C([R])C1=O</smiles>
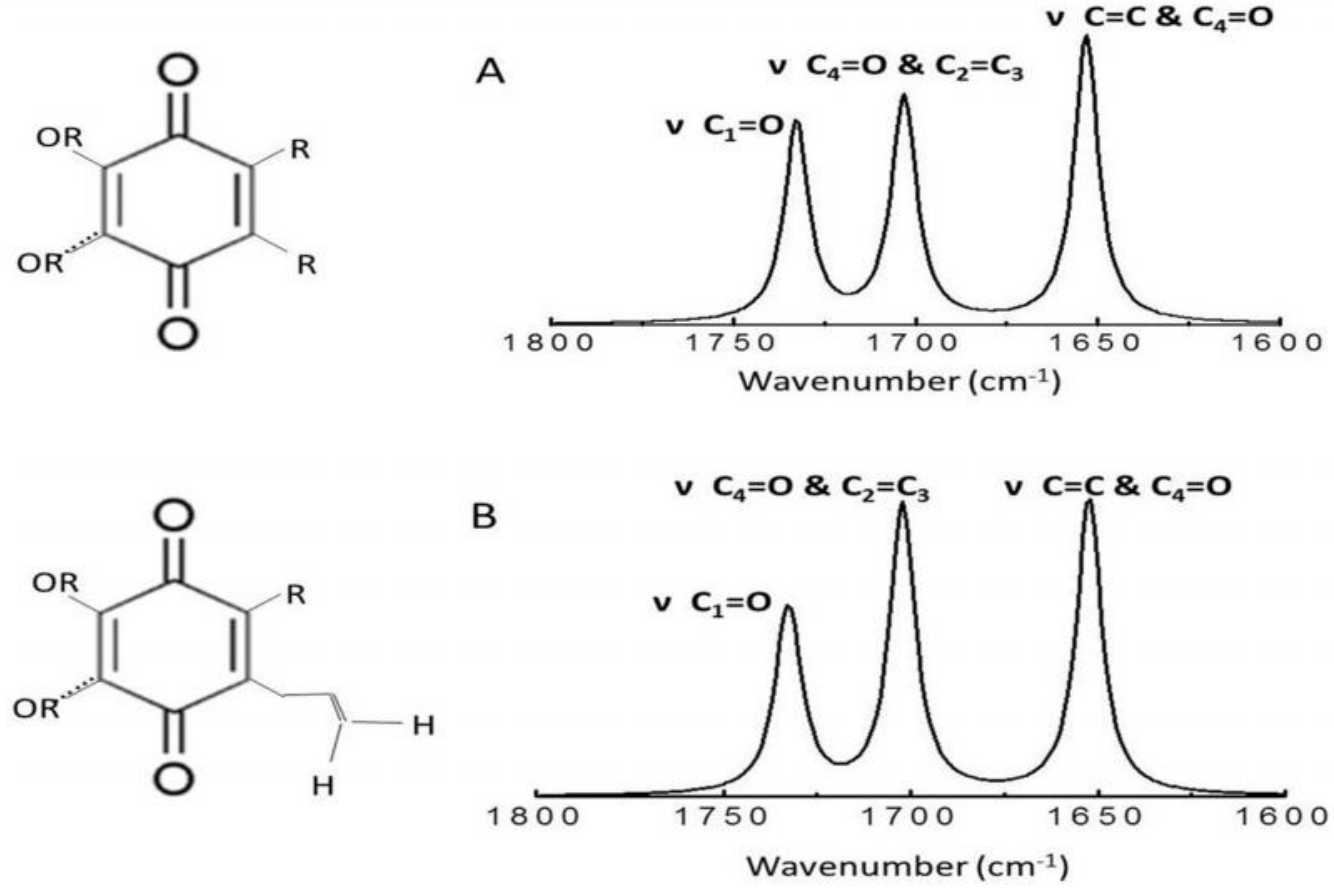

Fig. 6: Structure and gas phase calculated IR spectra in the uncoupled and coupled $\mathrm{C}-\mathrm{O}$ and $\mathrm{C}-\mathrm{C}$ vibrating region for the (A) MQo and (B) UQ. For the sake of simplicity $\mathrm{R}$ is written instead of $\mathrm{CH}_{3}$. 

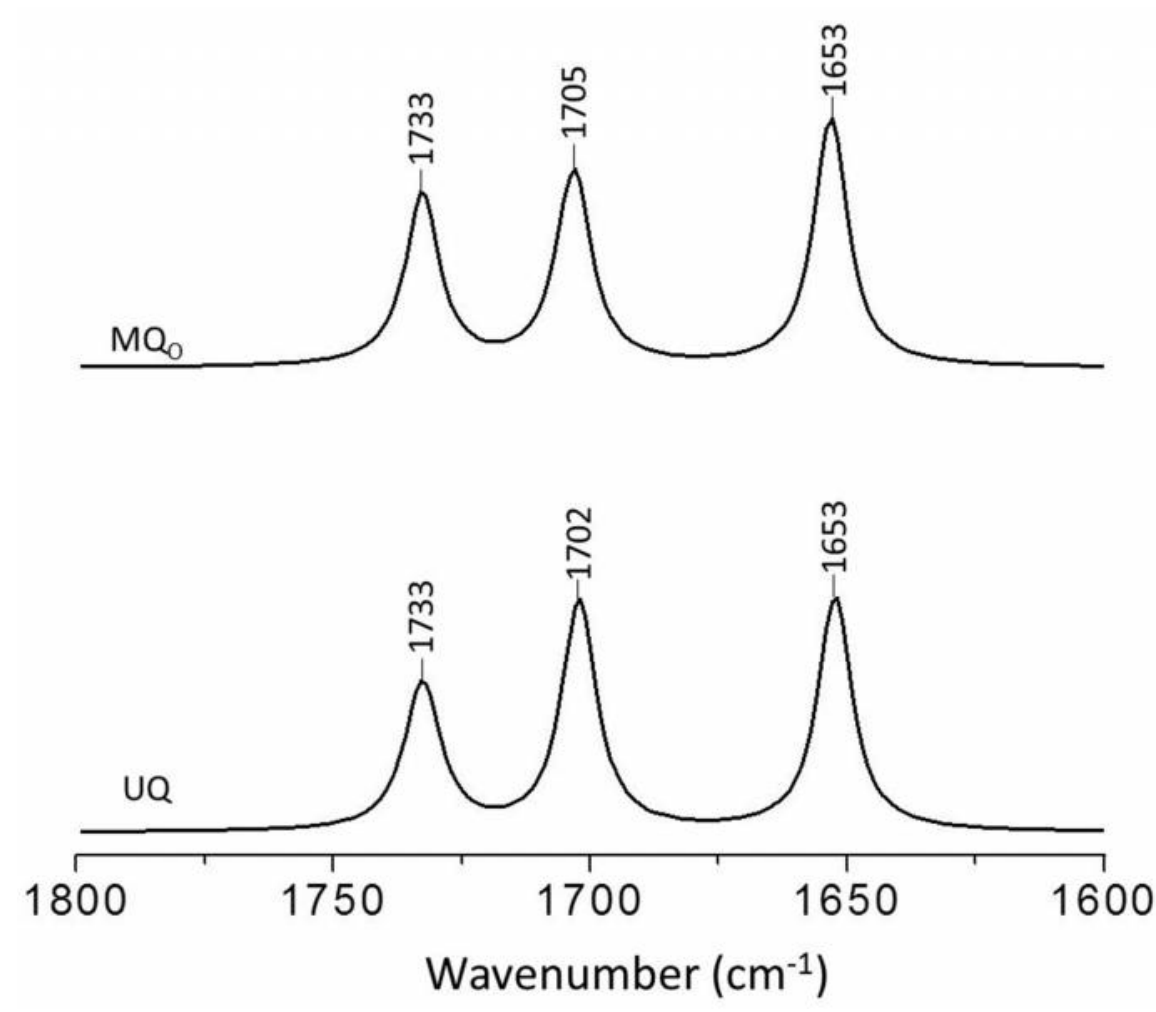

Fig. 7: Calculated IR absorption spectra of UQ and $\mathrm{MQ}_{0}$ in gas phase. The spectra are generated from the calculated stick spectra by convolving with Gaussian function of wavenumber $4 \mathrm{~cm}^{-1}$.

The IR spectra of UQ and MQo had shown three prominent bands in the $1800-1600 \mathrm{~cm}^{-1}$ region. For both quinones (UQ/MQo) bands are observed, respectively, at 1652/1653, 1702/1705, and 1733/1733 $\mathrm{cm}^{-1}$. The first two bands are occurred due to coupled vibration, whereas cause of the last band is due to single mode vibration. In fact, band at $1652 / 1653 \mathrm{~cm}^{-1}$ of $\mathrm{UQ} / \mathrm{MQ}_{\mathrm{O}}$ are predominantly due to antisymmetric $\mathrm{C}=\mathrm{C}_{\mathrm{r}}\left(\mathrm{C}_{2}=\mathrm{C}_{3}\right.$ and $\left.\mathrm{C}_{5}=\mathrm{C}_{6}\right)$ vibration coupled to the $\mathrm{C}_{4}=\mathrm{O}$ vibration and band at $1702 / 1705 \mathrm{~cm}^{-1}$ is predominantly due to $\mathrm{C}_{4}=\mathrm{O}$ vibration mixed with $\mathrm{C}_{2}=\mathrm{C}_{3}$ vibration. However, uncoupled $\mathrm{C}_{1}=\mathrm{O}$ vibration produced band at $1733 \mathrm{~cm}^{-1}$ for both of them. In MQo presence of two methyl side groups contributed more to the band at $1653 \mathrm{~cm}^{-1}$ and hence it is more intense. But, in UQ due to single methyl side group the intensity of bands at 1653 and $1702 \mathrm{~cm}^{-1}$ are same. The observation of UQ is in closer agreement with the work done by Lamichhane and Hastings [9].

In figure (7), we observed the similar nature of spectra for both UQ and MQ. The band due to single mode vibrations are not shifted. In addition to that, the coupled vibrations are slightly deviated and deviation is less than $3 \mathrm{~cm}^{-1}$. It further strengthens our conclusion that the addition of side group does not bring change in the nature of the spectra. 


\section{iii. The Solvent Effect}

Table 3: Bond length of carbonyl group and $C=C_{r}$ in $(\AA)$ unit of optimized structure of UQ, and MQo in Gas Phase (GP), $\mathrm{CCl}_{4}$, and Crystal Structure (CS).

\begin{tabular}{|c|c|c|c|c|c|c|c|c|c|c|c|c|}
\hline \multirow[t]{2}{*}{ Types } & \multicolumn{3}{|c|}{$\mathrm{C}_{1}=\mathrm{O}$} & \multicolumn{3}{|c|}{$\mathrm{C}_{4}=\mathrm{O}$} & \multicolumn{3}{|c|}{$\mathrm{C}_{2}=\mathrm{C}_{3}$} & \multicolumn{3}{|c|}{$\mathrm{C}_{5}=\mathrm{C}_{6}$} \\
\hline & GP & $\mathrm{CCl}_{4}$ & CS & GP & $\mathrm{CCl}_{4}$ & $\mathrm{CS}$ & GP & $\mathrm{CCl}_{4}$ & $\mathrm{CS}$ & GP & $\mathrm{CCl}_{4}$ & $\mathrm{CS}$ \\
\hline $\mathrm{MQ}_{\mathrm{O}}$ & 1.223 & 1.225 & 1.234 & 1.231 & 1.232 & 1.232 & 1.364 & 1.364 & 1.404 & 1.354 & 1.354 & 1.419 \\
\hline UQ & 1.223 & 1.225 & 1.234 & 1.231 & 1.232 & 1.232 & 1.364 & 1.364 & 1.404 & 1.354 & 1.355 & 1.419 \\
\hline
\end{tabular}

By analyzing table (3) and figure (8), we came to the conclusion that frequency of both UQ and MQo decreased in the solvent phase calculation than that of in the gas phase in the $1800-1600 \mathrm{~cm}^{-1}$ region. As a matter of fact, amount of decrement of particular IR band depend upon amount of change in bond length of the functional group that contributes to that specific band and they follows inverse relation. For example, bond length of $\mathrm{C}=\mathrm{C}$ remains almost same for both types of quinones in both phase calculations. Hence, very slight decrement in the band at $1653 \mathrm{~cm}^{-1}$, that is occurred predominantly due to antisymmetric $C=C_{r}\left(C_{2}=C_{3}\right.$ and $\left.C_{5}=C_{6}\right)$ vibration coupled to the $C_{4}=O$ vibration, is observed. On the other hand, $\mathrm{C}_{1}=\mathrm{O}$ mode shifted down nearly by $11 \mathrm{~cm}^{-1}$ and hence corresponding bond length increases by $0.002 \AA$. Similarly, lengthing of $\mathrm{C}_{4}=\mathrm{O}$ (of UQ and $\mathrm{MQ}_{\mathrm{O}}$ ) by $0.001 \AA$ leads to the lowering of bands at $1702 \mathrm{~cm}^{-1}$ (UQ) and $1705 \mathrm{~cm}^{-1}$ (MQo) to $1695 \mathrm{~cm}^{-1}$ (UQ) and $1696 \mathrm{~cm}^{-1}$ (MQo).
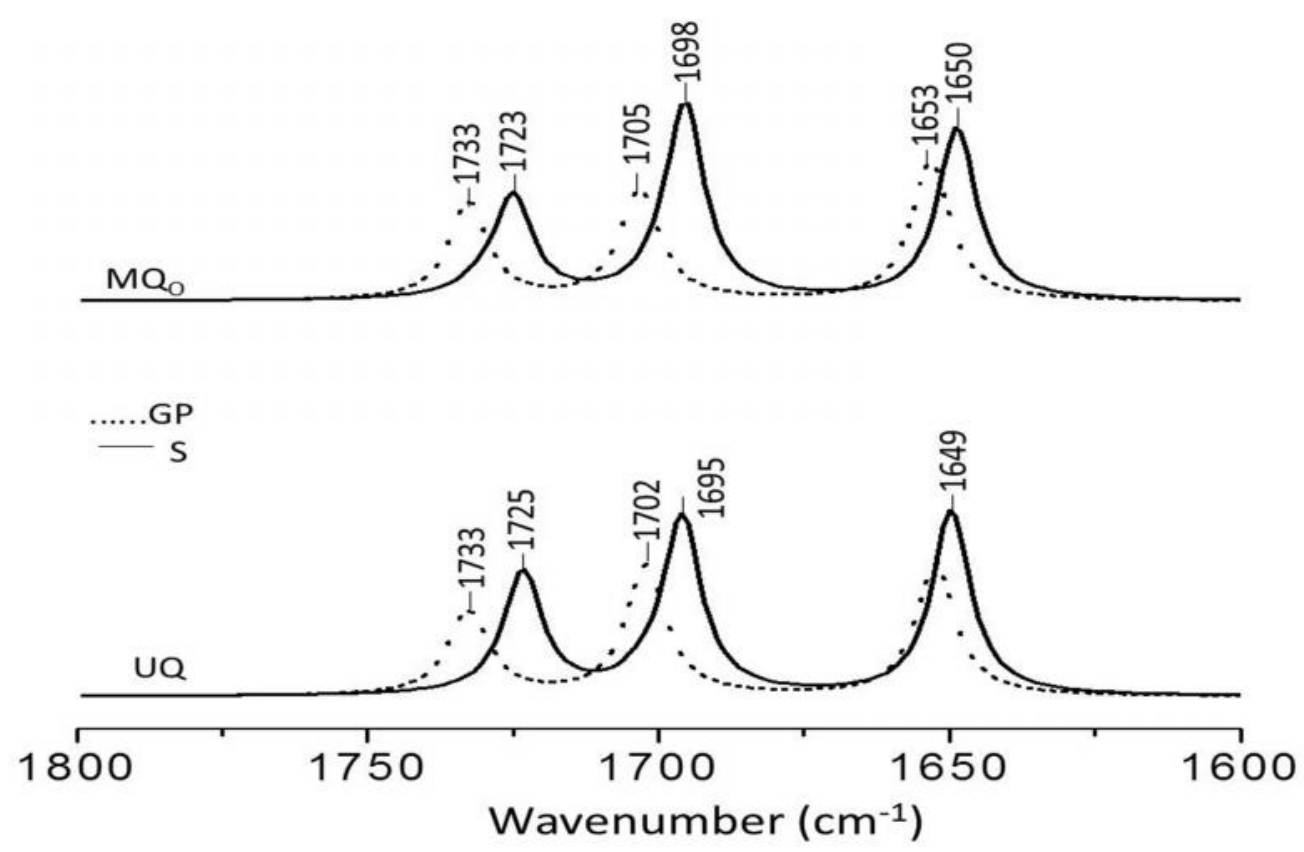

Fig. 8: Comparative spectra of UQ and $\mathrm{MQ}_{0}$ in gas phase and $\mathrm{CCl}_{4}$. The Spectra are generated from the calculated stick spectra by convolving with Gaussian function of wavenumber $4 \mathrm{~cm}^{-1}$. 


\section{Conclusions}

By studding IR spectra in gas phase and $\mathrm{CCl}_{4}$ of two different benzoquinones (with and without methoxy side group), we reach to the following conclusions. For the benzoquinones without methoxy side group (benzoquinone, duroquinone, and plastoquinone) two prominent IR bands are observed. The highly intense band is due to asymmetric $\mathrm{C}=\mathrm{O}\left(\mathrm{C}_{1}=\mathrm{O}\right.$ and $\left.\mathrm{C}_{4}=\mathrm{O}\right)$ vibration, while weak one is due to asymmetric $\mathrm{C}=\mathrm{C}_{\mathrm{r}}\left(\mathrm{C}_{2}=\mathrm{C}_{3}\right.$ and $\left.\mathrm{C}_{5}=\mathrm{C}_{6}\right)$ vibration. But, for the benzoquinones with methoxy side groups (ubiquinone, dimethoxy dimethyl benzoquinone) three prominent IR bands in different (high/intermediate/low) frequency is observed. Here, high/intermediate/low frequency bands are due to $\mathrm{C} 1=\mathrm{O} /$ coupled $\mathrm{C}_{4}=\mathrm{O}$ and $\mathrm{C}_{2}=\mathrm{C}_{3}$ / coupled asymmetric $\mathrm{C}=\mathrm{C}_{\mathrm{r}}$ and $\mathrm{C}_{4}=\mathrm{O}$ vibration. Moreover, addition of methyl side groups lowered the band positions carbonyl vibrations in proportion to the number of methyl groups. Furthermore, upon solvent phase calculation prominent lowering in the intense carbonyl band is seen.

\section{Acknowledgement}

For providing Gaussian 03 and computational facilities we want to acknowledge Central Department of Physics.

\section{References}

[1] S. Patai, The Chemistry of Quinonoid Compounds, John Willey \& Sons, New York, (1974).

[2] B. L. Trumpower, Functions of Quinones in Energy Converting Systems, Academic, New York, (1982).

[3] B. Ke, Photosynthesis: Photobiochemistry and Photobiophysics, Kluwer Academic Publishers, (2001).

[4] M. Y. Okamura, M. L. Paddock, M. S. Graige, and G. Feher., Proton and electron transfer in bacterial reaction centers. Biochemia et Biophysica Acta 1458 (2000) 148.

http://dx.doi.org/10.1016/S0005-2728(00)00065-7

[5] M. J. Frisch, G. W. Trucks, H. B. Schlegel, G. E. Scuseria, M. A. Robb, J. R. Cheeseman, Jr., J. A. Montgomery, T. Vreven, K. N. Kudin, J. C. Burant, J. M. Millam, S. S. Iyengar, J. Tomasi, V. Barone, B. Mennucci, M. Cossi, G. Scalmani, N. Rega, G. A. Petersson, H. Nakatsuji, M. Hada, M. Ehara, K. Toyota, R. Fukuda, J. Hasegawa, M. Ishida, T. Nakajima, Y. Honda, O. Kitao, H. Nakai, M. Klene, X. Li, J. E. Knox, H. P. Hratchian, J. B. Cross, V. Bakken, C. Adamo, J. Jaramillo, R. Gomperts, R. E. Stratmann, O. Yazyev, A. J. Austin, R. Cammi, C. Pomelli, J. W. Ochterski, P. Y. Ayala, K. Morokuma, G. A. Voth, P. Salvador, J. J. Dannenberg, V. G. Zakrzewski, S. Dapprich, A. D. Daniels, M. C. Strain, O. Farkas, D. K. Malick, A. D. Rabuck, K. Raghavachari, J. B. Foresman, J. V. Ortiz, Q. Cui, A. G. Baboul, S. Clifford, J. Cioslowski, B. B. Stefanov, G. Liu, A. Liashenko, P. Piskorz, I. Komaromi, R. L. Martin, D. J. Fox, T. Keith, M. A. Al-Laham, C. Y. Peng, A. Nanayakkara, M. Challacombe, P. M. W. Gill, B. Johnson, W. Chen, M. W. Wong, C. Gonzalez, and J. A. Pople, Gaussian, Inc., Wallingford CT, (2004). 
[6] G. Socrates, Infrared and Raman Characteristic group Frequencies: Table and Chart, John Wiley \& Sons, $3^{\text {rd }}$ Ed. (2004).

[7] M. H. Stowell, S. M. Soltis, T. M. MacPhillips, E. C. Abresch, D. C. Rees, and G. Feher, Science 276 (1997) 812.

[8] J. Coates, Interpretation of Infrared Spectra, A Practical Approach, John Willy \& Sons Ltd., Chichester, (2000).

[9] H. P. Lamichhane, Calculated Vibrational Properties of Quinones in Photosynthetic Re- action Centers, PhD Thesis, Georgia State University, USA, (2011). 